\title{
Analysis of Annual Energy Use Intensities (EUIs) by End-Use in Apartment Units According to Stratification Variables (2017 -
}

\author{
2018) \\ Hye-Sun $\mathrm{Jin}^{1}$, Han-Young Lim², You-Jeong, Kim ${ }^{2}$, Soo-Jin Lee ${ }^{1}$, Sung-Im Kim ${ }^{1}$, Jae-Han Lim $^{3}$, and Seung-Yeong Song ${ }^{3, *}$ \\ ${ }^{1} \mathrm{PhD}$. Student, Department of Architectural \& Urban Systems Engineering, Ewha Womans University, South Korea \\ ${ }^{2}$ Graduate Student, Department of Architectural \& Urban Systems Engineering, Ewha Womans University, South Korea \\ ${ }^{3}$ Professor, Department of Architectural \& Urban Systems Engineering, Ewha Womans University, South Korea
}

\begin{abstract}
To achieve the goal of reducing greenhouses gases, many countries have recognized the importance of energy conservation in the building sector, and such countries are considerably strengthening their building energy conservation policies by reinforcing design standards, encouraging remodeling, and requiring zero-energy construction. In order to effectively strengthen these policies, it is necessary to provide information concerning energy consumption in the building sector to ensure the technical and economic feasibility of policies in the marketplace, and to allow building users and policy makers to easily access and understand energy consumption characteristics. It is important to provide information that allows people to effectively understand the state of energy consumption by end-use (space heating, space cooling, domestic hot water, etc.) as part of the creation of a concrete plan for energy reduction that incorporates various service systems and is familiar to people. This is because providing such information plays an important role in establishing concrete policies and encouraging voluntary energy performance improvements by building occupants. South Korea operates the Korea Energy Statistics Information System (KESIS) and the information provided by this type of information system consists mainly of energy consumption by energy source (electricity, gas, etc.), and such systems remain inadequate for providing effective information on energy consumption and energy use intensity (EUI) by end-use (space heating, space cooling, domestic hot water, etc.) as part of the creation of a concrete plan for energy conservation. In order to accurately provide energy consumption information by end-use rather than limit the information to mainly consumption corresponding to energy sources, in this study, measurement systems were installed in $2014 \sim 2016$ based on the overall sampling designs of previous studies for apartment units, classifications, measurement and data gathering methods for energy consumption by end-use. The annual statistical values for EUI by end-use were collected from the measurement data for 71 sample apartment units from May 2017 to April 2018. This data was calculated and analyzed using stratification variable levels for completion year, supplied area, and the heat source type.
\end{abstract}

\section{Introduction}

\subsection{Background}

To achieve the goal of reducing greenhouses gases, many countries have recognized the importance of energy conservation in the building sector, and such countries are considerably strengthening their building energy conservation policies by reinforcing design standards, encouraging remodeling, and requiring zeroenergy construction. In order to effectively strengthen these policies, it is necessary to provide information concerning energy consumption in the building sector to ensure the technical and economic feasibility of policies in the marketplace, and to allow building users and policy makers to easily access and understand energy consumption characteristics. It is important to provide information that allows people to effectively understand the state of energy consumption by end-use (space heating, space cooling, domestic hot water (DHW), lighting, air movement, etc.) as part of the creation of a concrete action plan for energy reduction that incorporates various service systems and is familiar to people. This is because providing such information plays an important role in establishing concrete policies and encouraging voluntary energy performance improvements by building occupants.

Many countries currently operate energy consumption information systems in building sector, and major examples include the United States' Residential Energy Consumption Survey (RECS) [1] and Commercial Building Energy Consumption Survey (CBECS) [2]. Such systems employ sample building surveys and data collected from energy suppliers to provide information regarding energy consumption corresponding to the building type (residential, commercial, etc.), building characteristics, and energy sources (electricity, gas, etc.). They also provide information concerning energy consumption and energy use intensity (EUI) by end-use

* Corresponding author: archssy@ewha.ac.kr 
Table 1. Number of sample apartment units by stratified variable and level for estimating energy use intensity

\begin{tabular}{|c|c|c|c|c|c|}
\hline Completion year & $\begin{array}{c}\text { Number of sample } \\
\text { units }\end{array}$ & $\begin{array}{c}\text { Type of heat } \\
\text { source }\end{array}$ & $\begin{array}{c}\text { Number of sample } \\
\text { units }\end{array}$ & $\begin{array}{c}\text { Supplied area of } \\
\text { unit }\left(\mathrm{m}^{2}\right)\end{array}$ & $\begin{array}{c}\text { Number of sample } \\
\text { units }\end{array}$ \\
\hline 1993 or earlier & $22(31 \%)$ & District heating & $21(30 \%)$ & Less than 66.0 & $12(17 \%)$ \\
\hline 2003 or earlier & $19(27 \%)$ & Individual heating & $50(70 \%)$ & Less than 115.5 & $42(59 \%)$ \\
\hline 2004 or later & $30(42 \%)$ & - & - & 115.5 or more & $17(24 \%)$ \\
\hline Sum & 71 & Sum & 71 & Sum & 71 \\
\hline
\end{tabular}

Table 2. Installed systems for measuring energy consumption by end-use

\begin{tabular}{|c|c|c|c|}
\hline $\begin{array}{c}\text { Space } \\
\text { heating }\end{array}$ & $\begin{array}{c}\text { Space } \\
\text { cooling }\end{array}$ & DHW & Lighting \\
\hline & & & \\
\hline
\end{tabular}

(space heating, space cooling, domestic hot water (DHW), lighting, air movement, etc.), which is calculated through statistical processing and engineering models created using the collected data. This information can be effectively employed to establish concrete plans for energy conservation.

South Korea operates the Korea Energy Statistics Information System (KESIS), which employs three-year energy surveys and one-year permanent household sample surveys to provide energy consumption information by building type (residential, commercial/public, large-scale), building characteristics, and energy source (electricity, gas, etc.). A green construction portal (Green Together) was created by collecting energy suppliers' fee charging data, with the goal of issuing energy evaluation reports for a building energy consumption certification system. The portal provides a function for comparing individual buildings' energy consumptions by energy source (electricity, gas, etc.) with similar types of buildings. However, the information provided by this type of information system consists mainly of energy consumption by energy source (electricity, gas, etc.), and such systems remain inadequate for providing effective information on energy consumption and energy use intensity (EUI) by end-use (space heating, space cooling, domestic hot water (DHW), lighting, air movement, etc.) as part of the creation of a concrete plan for energy conservation. In order to accurately provide energy consumption information by end-use rather than limit the information to mainly consumption corresponding to energy sources, systems for continuously measuring energy consumption by end-use are being installed in sample apartment units and complexes (public areas) and office buildings over the course of six years, beginning in 2014. A national research project is being performed that statistically processes the measured data to construct an information system for energy use and $\mathrm{CO}_{2}$ emission intensities by end-use. In this study, measurement systems were installed in $2014 \sim 2016$ based on the overall sampling designs of previous studies for apartment units, classifications, measurement and data gathering methods for energy consumption by end-use. The annual statistical values for EUI by end-use were collected from the measurement data for 71 sample apartment units from May 2017 to April 2018 and this data was calculated and analyzed.

\subsection{Overview \& Methodology}

In this study, overall sampling designs of the apartment units in apartment buildings, classification and definition of site energy consumption by end-use, measurement of energy consumption by end-use and data collection methods from previous studies [3-5] are discussed. In this study, 71 apartment units in Seoul, South Korea whose energy meters were installed between 2014 and 2016 were selected, and the site energy consumption data of these apartment units for one year between May in 2017 and April in 2018 were collected. The site energy use intensity (EUI) was calculated by dividing the site energy consumption by the area of each apartment unit $\left(\mathrm{m}^{2}\right)$. To examine the EUI distribution characteristics in the entire sample, the statistics including average, maximum, minimum, and percentile $(10 \%, 25 \%, 50 \%, 75 \%$, and $90 \%)$ were calculated. Furthermore, to examine the validity of the calculated EUI statistics, the average site EUI by end-use were calculated and compared with the EUI values from the United States Residential Energy Consumption Survey (RECS) 2015.

\section{Measurement of energy consumption by end-use of apartment units}

In accordance with the requirements of relevant systems (e.g., Building Energy Efficiency Rating System and Total Building Annual Energy Standard, etc.), site energy consumptions by end-use were classified into space heating, space cooling, domestic hot water (DHW), lighting, air movement, space heating circulation (included in space heating), and domestic hot water circulation (included in DHW). To reflect site energy classification in ISO 12655:2013 and consider large energy consuming items in typical apartment units of 
Table 3. Annual site energy use intensity per area by end-use $\left(\mathrm{kWh} / \mathrm{m}^{2}\right.$.year).

\begin{tabular}{|c|c|c|c|c|c|c|c|c|c|}
\hline \multicolumn{2}{|c|}{ Classification } & $\begin{array}{c}\text { Space } \\
\text { heating }\end{array}$ & $\begin{array}{l}\text { Space } \\
\text { cooling }\end{array}$ & DHW & Lighting & $\begin{array}{c}\text { Air } \\
\text { movement }\end{array}$ & $\begin{array}{c}\text { Electric } \\
\text { appliances }\end{array}$ & Cooking & Total \\
\hline \multicolumn{2}{|c|}{$\begin{array}{c}\text { Average } \\
\text { (Representative value) }\end{array}$} & 83.5 & 1.5 & 24.8 & 5.4 & 0.4 & 41.5 & 11.4 & 141.2 \\
\hline \multicolumn{2}{|c|}{ Maximum } & 147.9 & 3.6 & 52.0 & 10.8 & 1.3 & 60.6 & 26.9 & 227.8 \\
\hline \multicolumn{2}{|c|}{ Minimum } & 29.8 & 0.3 & 4.5 & 2.6 & 0.0 & 23.8 & 4.2 & 56.6 \\
\hline \multirow{5}{*}{ Percentile } & $10 \%$ & 38.0 & 0.5 & 12.6 & 2.7 & 0.1 & 26.0 & 5.2 & 78.4 \\
\hline & $25 \%$ & 55.5 & 0.7 & 14.3 & 3.5 & 0.2 & 32.6 & 8.8 & 107.3 \\
\hline & $50 \%$ & 79.4 & 1.3 & 23.1 & 4.6 & 0.3 & 41.4 & 11.1 & 138.4 \\
\hline & $75 \%$ & 112.2 & 2.0 & 35.0 & 7.4 & 0.6 & 49.1 & 13.7 & 176.0 \\
\hline & $90 \%$ & 127.7 & 3.1 & 41.4 & 8.4 & 0.8 & 58.7 & 16.2 & 205.8 \\
\hline \multicolumn{2}{|c|}{ Standard deviation } & 35.5 & 1.0 & 12.8 & 2.3 & 0.3 & 11.8 & 5.0 & 48.7 \\
\hline \multicolumn{2}{|c|}{ Ratio based on average } & $49.5 \%$ & $0.9 \%$ & $14.7 \%$ & $3.2 \%$ & $0.2 \%$ & $24.6 \%$ & $6.8 \%$ & - \\
\hline
\end{tabular}

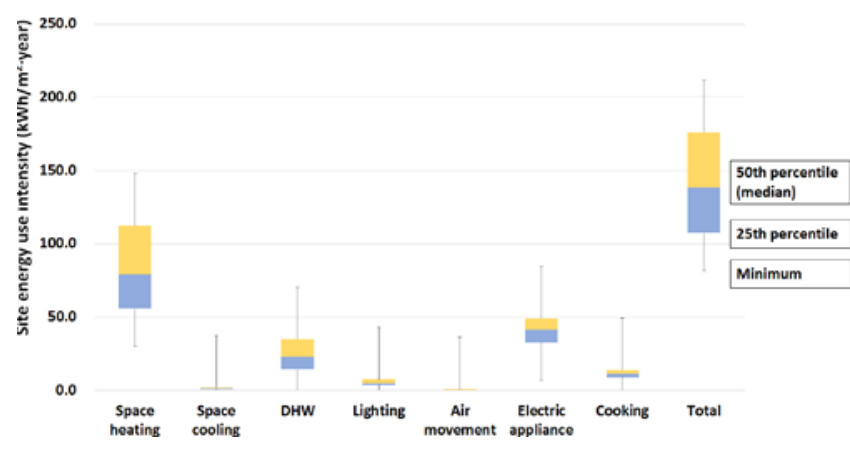

Fig. 1. Box-plot of annual site energy use intensity per area by end-use $\left(\mathrm{kWh} / \mathrm{m}^{2} \cdot\right.$ year$)$.

apartment buildings, site energy consumptions for measurement and normalization were further classified to space cooling, electric appliances and cooking. Based on site energy consumption classification and definition, measurement and data collection methods used in previous studies, energy meters were installed at 71 sample units in apartment buildings in Seoul, South Korea to monitor site energy consumption by end-use. Table 1 summarizes information for the apartment units (e.g., construction completion year, heating type, and supplied area $\left.\left(\mathrm{m}^{2}\right)\right)$. And installed systems for measuring energy consumption by end-use are listed in Table 2 .

\section{Statistical analysis of site energy intensity (EUI) by end-use}

\subsection{Normalization and statistical analysis of energy consumption by end-use}

To calculate and analyze the EUI statistical values by end-use gathered from the sample unit measurements, the annual values for site energy were collected from May 2017 to April 2018, and these were divided by the sample units' exclusive use area $\left(\mathrm{m}^{2}\right)$ to determine the EUI values. Then, statistical values such as the average were calculated and analyzed to understand the EUI distribution characteristics of the overall sample. The statistical values were calculated to understand the overall sample's EUI distribution characteristics, and during the calculation of the statistical values the top and bottom $10 \%$ of EUIs for each sample were excluded in order to minimize the effects of overestimated or underestimated EUIs in a specific sample. The average, median, mode, and so on can be employed as the statistical values that represent the EUI distribution characteristics. This study's sample design is intended to estimate the population's average within a fixed allowable error, and so the average value was adopted as a representative value. It is difficult to concretely understand the EUI distribution characteristics using only the average value, and so the maximum, minimum, percentiles $(10 \%, 25 \%, 50 \%, 75 \%$, and $90 \%)$, and standard deviation values were also calculated.

\subsection{Annual site energy use intensity (EUI) by end-use}

The statistics on annual site end-use energy use intensity (EUI) and the ratio of site EUI to the average are summarized in Table 3 and the box plot graph for this data is shown in Figure 1. The average site EUI was the highest for space heating, followed by electric appliances, domestic hot water (DHW), cooking, lighting, space cooling, and air movement. Thus, space heating, electric appliances, and DHW showed high EUI values at 83.5, 41.5 and $24.8 \mathrm{kWh} / \mathrm{m}^{2}$.year. The EUI values for cooking and lighting were 11.4 and $5.4 \mathrm{kWh} / \mathrm{m}^{2}$.year, respectively. Space cooling and air movement showed low EUI values below $2.0 \mathrm{kWh} / \mathrm{m}^{2}$.year. The site EUI ratios by end-use were 49.5, 24.6, 14.7, 6.8 and $3.2 \%$ for space heating, electric appliances, DHW, cooking, and lighting, respectively. In other words, space heating has by far the largest site EUI in apartment unit in South Korea, the site EUI for electric appliances is about half that for space heating, and the site EUI for DHW is slightly smaller than that for electric appliances.

Furthermore, high standard deviations of site EUI were found for space heating, DHW, and electric appliances, implying that the EUI differences among the sample units for these uses are larger compared to other uses.

\footnotetext{
* Corresponding author: archssy@ewha.ac.kr
} 
Table 4. Monthly site energy use intensity per area by end-use $\left(\mathrm{kWh} / \mathrm{m}^{2} \cdot \mathrm{month}\right)$.

\begin{tabular}{|c|c|c|c|c|c|c|c|c|}
\hline Classification & $\begin{array}{c}\text { Space } \\
\text { heating }\end{array}$ & $\begin{array}{l}\text { Space } \\
\text { cooling }\end{array}$ & DHW & Lighting & $\begin{array}{c}\text { Air } \\
\text { movement }\end{array}$ & $\begin{array}{c}\text { Electric } \\
\text { appliances }\end{array}$ & Cooking & Total \\
\hline 2017.05 . & 1.2 & 0.0 & 2.0 & 0.4 & 0.033 & 3.3 & 0.9 & 6.7 \\
\hline 2017.06 & 0.0 & 0.1 & 1.2 & 0.4 & 0.032 & 3.3 & 0.9 & 6.0 \\
\hline 2017.07. & 0.0 & 0.7 & 0.9 & 0.4 & 0.033 & 4.1 & 0.9 & 6.9 \\
\hline 2017.08 & 0.0 & 0.5 & 0.8 & 0.4 & 0.033 & 3.9 & 0.9 & 6.4 \\
\hline 2017.09. & 0.8 & 0.0 & 1.1 & 0.4 & 0.032 & 3.2 & 0.9 & 5.9 \\
\hline 2017.10. & 2.5 & 0.0 & 1.4 & 0.5 & 0.033 & 3.3 & 0.9 & 8.0 \\
\hline 2017.11. & 9.3 & 0.0 & 2.1 & 0.5 & 0.031 & 3.2 & 1.0 & 13.8 \\
\hline 2017.12. & 17.0 & 0.0 & 3.2 & 0.5 & 0.033 & 3.5 & 1.0 & 20.2 \\
\hline 2018.01. & 19.7 & 0.0 & 3.4 & 0.5 & 0.033 & 3.6 & 0.9 & 22.0 \\
\hline 2018.02 & 16.4 & 0.0 & 3.5 & 0.5 & 0.030 & 3.3 & 0.9 & 19.0 \\
\hline 2018.03. & 9.5 & 0.0 & 3.0 & 0.5 & 0.033 & 3.5 & 1.0 & 13.4 \\
\hline 2018.04. & 5.0 & 0.0 & 2.2 & 0.5 & 0.034 & 3.2 & 0.9 & 9.8 \\
\hline
\end{tabular}

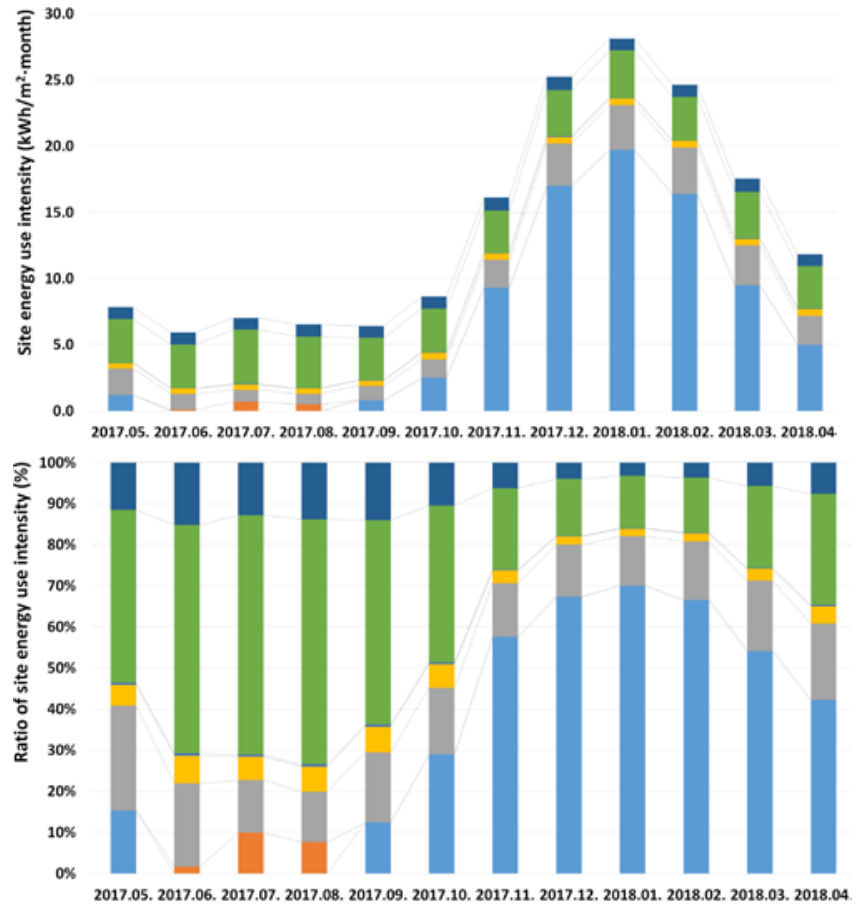

| Space heating $\mid$ Space cooling $\mid=\mathrm{DHW}=$ Lighting $\mid$ Air movement $\mid$ Electric appliance $\mid$ Cooking

Fig. 2. Pattern profile of monthly site energy use intensity per area by end-use $\left(\mathrm{kWh} / \mathrm{m}^{2} \cdot \mathrm{month}\right)$.

The average site EUI for all apartment units was 141.2 $\mathrm{kWh} / \mathrm{m}^{2}$ year.

\subsection{Monthly site energy use intensity (EUI) by end-use}

The statistics on the monthly site EUI by end-use are summarized in Table 4 and the monthly pattern profile is shown in Figure 2. The site EUI for space heating started to gradually increase in from November 2017 when the space heating season began, reached the peak of 19.7 $\mathrm{kWh} / \mathrm{m}^{2} \cdot$ month in January 2018 and stayed somewhat until March in 2018. On the other hand, site EUI for cooking was so high for two months in July and August in 2017 and recorded the peak site EUI of 0.7 $\mathrm{kWh} / \mathrm{m}^{2} \cdot$ month in July 2017 . For electric appliances, the site EUI was relatively high at approximately 4.0 $\mathrm{kWh} / \mathrm{m}^{2} \cdot \mathrm{month}$ in July and August in 2017, which appears to be associated with the increased use of space cooling during this period. Furthermore, the site EUI for DHW, lighting, air movement, and cooking relatively stayed the same throughout the year, as they are less affected by season.

\section{Validation of average site EUI by end- use}

To validate the statistics on site EUI for 71 sample apartment units in 16 complexes in Seoul for one year from May 2017 and April 2018, the average site EUI were compared to the site EUI for homes in the MixedHumid region in 2015 from the RECS [15,16]. According to the International Climate Zone definitions in ASHRAE Standard 90.1 [17], Seoul corresponds to Zone 4 (Mixed-Humid zone). RECS 2015 includes data for various residential types such as single-family detached, single-family attached, apartments in 2-4 unit buildings, apartments in 5 or more unit buildings, and mobile homes. The site energy consumption by end-use is separately determined using statistical techniques on total energy consumption based on energy bills, etc.

Table 5. Average site energy consumption per housing unit in mixed-humid climate region of RECS 2015.

\begin{tabular}{|c|c|c|c|}
\hline & Space heating & Space cooling & DHW \\
\hline $10^{6} \mathrm{Btu}$ & 35.7 & 6.9 & 15.1 \\
\hline $\mathrm{kWh}$ & $10,463.6$ & $2,022.2$ & $4,425.4$ \\
\hline & Refrigerator & Others* & Total \\
\hline $10^{6} \mathrm{Btu}$ & 2.6 & 21.3 & 80.7 \\
\hline $\mathrm{kWh}$ & 762.0 & $6,242.4$ & $23,650.8$ \\
\hline
\end{tabular}

Table 6. Average area per housing unit in mixed-humid climate region of RECS 2015.

\begin{tabular}{|c|c|c|}
\hline Total & Heated & Cooled \\
\hline $2,073 \mathrm{ft}^{2}$ & $\mathbf{1 , 7 7 1 f ^ { 2 }}$ & $1,530 \mathrm{ft}^{2}$ \\
\hline $192.6 \mathrm{~m}^{2}$ & $\mathbf{1 6 4 . 5 m ^ { 2 }}$ & $142.1 \mathrm{~m}^{2}$ \\
\hline
\end{tabular}

\footnotetext{
* Corresponding author: archssy@ewha.ac.kr
} 
Table 7. Site energy use intensities by end-use of this study and RECS $2015\left(\mathrm{kWh} / \mathrm{m}^{2}\right.$.year).

\begin{tabular}{|c|c|c|c|c|c|}
\hline & Space heating & Space cooling & DHW & Electric appliance, etc. & Total \\
\hline This study & $83.5(31.3 \%)$ & $1.5(-87.8 \%)$ & $24.8(-7.8 \%)$ & $58.7(37.8 \%)$ & $141.2(-1.7 \%)$ \\
\hline RECS 2015 & $63.6(0.0 \%)$ & $12.3(0.0 \%)$ & $26.9(0.0 \%)$ & $42.6(0.0 \%)$ & $143.7(0.0 \%)$ \\
\hline
\end{tabular}

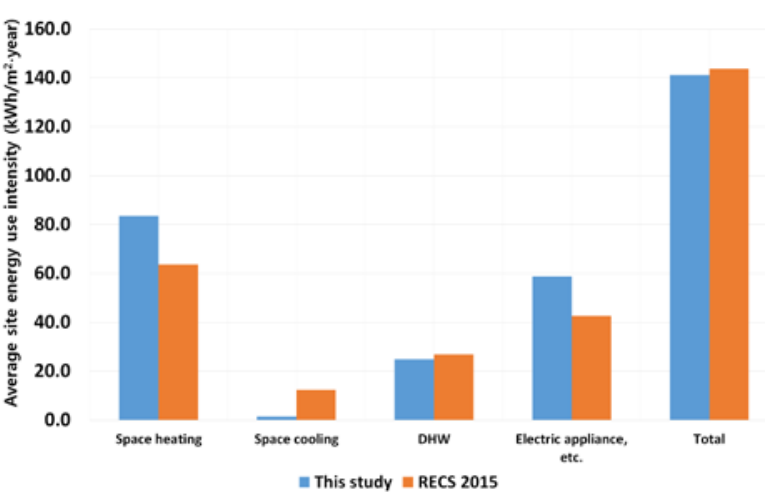

Fig. 3. Comparison of site energy use intensities by enduse of this study and RECS $2015\left(\mathrm{kWh} / \mathrm{m}^{2}\right.$.year)

Table 5 and Table 6 show the site energy consumption per housing unit, the average area of house, and the unit conversion result in the Mixed-Humid region of the United States. In calculating the site EUI in this study, the area of each household is considered to be equivalent to the space heating area. Therefore, the average site energy consumption per housing unit in Table 5 was divided by the average space heating area per housing unit in Table 6 to calculate the site EUI.

The classification of end-uses in RECS 2015 is different from this study. As shown in Table 5, refrigerator in RECS 2015 corresponds to electric appliances in the present study. Miscellaneous items (e.g., Lighting, appliances, and electronics) in RECS 2015 corresponding to lighting, air movement, electric appliances, and cooking in the present study. For an accurate comparison between this study and RECS 2015, the site EUI for lighting, air movement, electric appliances, and cooking from this study were combined into electric appliance, etc., and site EUI for refrigerator and miscellaneous items in RECS 2015 were combined for electric appliance, etc. Table 7 and Figure 3 show the results of comparison of site EUI between this study and RECS 2015.

The results indicate that the total average site EUI and that for DHW were very similar in both cases, but the results for the other end uses differed. The largest difference ratio between the results of this study and RECS 2015 was obtained for space cooling. The site EUIs for space heating and electric appliances, etc., obtained in this study were larger than those determined from the RECS 2015 data. However, the space cooling, DHW, and total site EUIs were larger for RECS 2015. The average site EUIs by end use had the same order in both this study and RECS 2105: space heating > electric appliances, etc. $>$ DHW $>$ space cooling.

The comparison target RECS 2015 data concerned households in a mixed-humid climate zone, and Seoul, where the sample units considered in this study were located, is classified as a mixed-humid climate zone. Therefore, the climate characteristics can be considered similar. The differences in EUIs for space heating, space cooling, and electric appliances, etc., are thought to be due to differences in operating times and frequently used electric appliances in accordance with the lifestyles of Korean apartment unit occupants (in Korea, rice cookers and auxiliary heaters are often used and consume considerable amounts of electricity), as well as differences in the evaluation years. The EUI difference for space cooling is thought to be have arisen because most units considered in this study had a daily average cooling time of less than 5 hours during the cooling period of July and August ( 2 months), in which sampleunit air conditioners were used. Further, the percentage of units that did not have air conditioners or in which air conditioners were not operated was very high, at $25 \%$. In addition, there were differences in the methods used to collect and process energy consumption data by end use in this study and in RECS 2015; this requires further consideration.

\section{Conclusion}

In this study, measurement systems were installed in $2014 \sim 2016$ to produce EUI statistical values for annual energy consumption for site energy by end-use. The data was calculated from May 2017 to April 2018, using the measurement data of 71 sample units in apartment complexes in the Seoul, South Korea, which is a Korean governmental region for which measurement data has been procured and validity of these data was evaluated by comparing them with the unit values for the U.S. RECS 2015. The findings of this study can be summarized as follows.

(1) The annual site EUI ratio (average) by end-use was the highest for space heating $(49.5 \%)$, followed by electric appliances $(24.6 \%)$, DHW (14.7\%), cooking (6.8\%), lighting (3.2\%), space cooling $(0.9 \%)$, and air movement $(0.2 \%)$. The annual site EUI of space heating, electric appliances, and DHW were large at $83.5,41.5$, and $24.8 \mathrm{kWh} / \mathrm{m}^{2} \cdot$ year, respectively. The annual site EUI of cooking and lighting were 11.4 and $5.4 \mathrm{kWh} / \mathrm{m}^{2}$ year, respectively. The annual site EUI of space cooling and air movement were small at less than 2.0 
$\mathrm{kWh} / \mathrm{m}^{2} \cdot$ year. The total EUI per apartment unit (average) is $141.2 \mathrm{kWh} / \mathrm{m}^{2} \cdot$ year.

(2) Space heating had the highest monthly site EUI of $19.7 \mathrm{kWh} / \mathrm{m}^{2}$.year in January 2018. The monthly site EUI for space cooling recorded the peak at $0.7 \mathrm{kWh} / \mathrm{m}^{2}$.year in July 2017 . In July and August 2018, the average monthly site EUI for electric appliances was 4.0 $\mathrm{kWh} / \mathrm{m}^{2}$ year, which is relatively high. The annual site EUI for other end-uses were relatively consistent throughout the year.

(3) Based on these results, space heating has the largest potential for reduction in site energy consumption.

(4) The annual site EUIs by end use obtained in this study were compared to the site EUIs by end use from RECS 2015 for the climate zone including Seoul; the total and DHW values were very similar, but those for the other end uses were different. In both this study and RECS 2015, the site EUIs by end use had the same order: space heating > electric appliances, etc. $>$ DHW $>$ space cooling.

The number of samples that will have their energy consumption measured by end-use is expected to continually increase until 2020 (up to a total of 200 samples), and the measured data will be continually collected to update the site energy, primary energy and $\mathrm{CO}_{2}$ emission EUI data by end-use.

This research was supported by a grant (19AUDPB079104-06) from Architecture \& Urban Development Research Program funded by Ministry of Land, Infrastructure and Transport of Korean government.

\section{References}

1. Residential Energy Consumption Survey (RECS), U.S. Energy Information Administration. Available online:

https://www.eia.gov/consumption/residential/ (accessed on 10 January 2019).

2. Commercial Building Energy Consumption Survey (CBECS), U.S. Energy Information Administration. Available online:

https://www.eia.gov/consumption/commercial/ (accessed on 10 January 2019).

3. B. Choi, H. Jin, J. Kang, S. Kim, J. Lim, S. Song. Meas. N. K 9, 6 (2015)

4. H. Jin, B. Choi, J. Kang, S. Kim., J. Lim, S. Song. Meas. N. E 96 (2016)

5. Korean Institute of Architectural Sustainable Environment and Building Systems. Meth.C. K S-6 (2016)
6. H. Jin, S. Lim, J. Kang, S. Kim, J. Lim, Y. Kim, S. Song. Exam. M. K 33, 7 (2017)

7. H. Jin, H. Lim, S. Lee, S. Kim, J. Lim, S. Song. Annu. I. K 34, 7 (2018)

8. E. Hossein. Buil. H. E 43 (2014)

9. T. Kristopher, D. Juan. Pred. M. E 128 (2016)

10. W. Daniel, L. Ines, F. Paulo, E. Jon. Resi. E. E 56 (2012)

11. C. Shuqin, Y. Hiroshi, D. Mark, L. Zhenhai. Cont. A. E 41 (2009)

12. C. Shuqin, L. Nianping, G. Jun, X. Yanqun, S. Fengmei, N. Ji. Stat. M. E 40 (2008)

13. A. Anna, T. Charles. Evid. R. E 52 (2015)

14. B. Debbie, F. David, L, Jieming, L, Jiang. Anal. E. E 79 (2015)

15. US Energy Information Administration, Table CE3.1, Household Site End-Use Consumption in the U.S., Totals and Averages, 2015, Available online: https://www.eia.gov/consumption/residential/data/2 015/c\&e/ce3.1.xlsx (accessed on 27 January 2019).

16. US Energy Information Administration, Table HC10.9, Average Square Footage of U.S. Homes, by Housing Characteristics, 2015, Available online: https:/www.eia.gov/consumption/residential/data/2 015/hc/hc10.9.xlsx (accessed on 27 January 2019).

17. ANSI/ASHRAE/IESNA Standard 90.1-2013, Energy Standard for Buildings Except Low-Rise Residential Buildings, American Society of Heating, Refrigerating, and Air-Conditioning Engineers (ASHRAE) 2013. 